\title{
PENGARUH CURRENT RATIO, DEBT TO EQUITY RATIO DAN FIRM SIZE TERHADAP RETURN ON EQUITY
}

\author{
Jufrizen \\ Fakultas Ekonomi dan Bisnis, Universitas Muhammadiyah Sumatera \\ Utara \\ jufrizen@umsu.ac.id \\ Maya Sari \\ Fakultas Ekonomi dan Bisnis, Universitas Muhammadiyah Sumatera \\ Utara \\ mayasari@umsu.ac.id
}

\begin{abstract}
The purpose of this study is to analyze whether variables such as Current Ratio, Debt to Equity Ratio and Company Size have a partial or simultaneous influence on Return On Equity. The approach taken in this study is an associative approach. The population in this study were all Agriculture Subsector Companies listed on the Indonesia Stock Exchange (IDX) which numbered 14 companies, while the samples that met the criteria in sampling for this study were 6 Agricultural Subsector Companies listed on the Indonesia Stock Exchange (IDX). Analysis of sample data used in this study is Multiple Linear Regression. The results of the study show that partially Current Ratio has no significant effect on Return On Equity, Debt to Equity Ratio has no significant effect on Return On Equity and Firm Size does not have a significant effect on Return On Equity. Simultaneous Results show that Current Ratio, Debt to Equity Ratio and Company Size have no significant effect on Return On Equity.
\end{abstract}

Keywords: Current Ratio, Debt to Equity Ratio, Firm Size, Return On Equity.

\begin{abstract}
Abstrak
Tujuan dari penelitian ini adalah untuk menganalisis apakah variabel-variabel seperti Current Ratio, Debt to Equity Ratio dan Ukuran Perusahaan memiliki pengaruh secara parsial maupun simultan terhadap Return On Equity.Pendekatan yang dilakukan dalam penelitian ini adalah pendekatan
\end{abstract}


assosiatif. Populasi dalam penelitian ini adalah seluruh Perusahaan Subsektor Pertanian yang terdaftar di Bursa Efek Indonesia (BEI) yang berjumlah 14 Perusahaan, sedangkan sampel yang memenuhi kriteria dalam penarikan sampel untuk penelitian ini adalah berjumlah 6 Perusahaan Subsektor Pertanian yang terdaftar di Bursa Efek Indonesia (BEI). Analisis data sampel yang digunakan dalam penelitian ini adalah Regresi Linier Berganda.Hasil Penelitian menunjukkan bahwa secara parsial Current Ratio tidak berpengaruh Signifikan terhadap Return On Equity, Debt to Equity Ratio tidak berpengaruh Signifikan terhadap Return On Equitydan Ukuran Paerusahaan tidak berpengaruh Signifikan terhadap Return On Equity. Hasil Simultan menunjukkan bahwa Current Ratio, Debt to Equity Ratio dan Ukuran Perusahaan tidak berpengaruh Signifikan terhadap Return On Equity.

\section{Kata Kunci : Current Ratio, Debt to Equity Ratio, Firm Size, Return On Equity.}

\section{PENDAHULUAN}

Saat ini, perekonomian di Indonesia mengalami pertumbuhan yang kian pesat menjadi perekonomian terbuka.Setiap perusahaan saling bersaing secara ketat untuk bisa mengikuti perkembangan perekonomian sehingga tidak tertinggal dan mengalami penurunan.Salah satu tujuan dari sebuah perusahaan adalah untuk memperoleh profitabilitas yang maksimal dari aktivitas operasionalnya. Aktivitas operasional perusahaan secara umum meliputi aktivitas produksi, distribusi, promosi, dan penjualan.Agar tujuan tersebut dapat tercapai, maka perusahaan memerlukan manajemen dengan tingkat efektifitas yang tinggi.Pengukuran tingkat efektifitas dapat dilihat dari laba yang diperoleh perusahaan.Besarnya laba yang diperoleh perusahaan dapat digunakan 
Jufrizen \& Maya Sari : Pengaruh Current Ratio, Debt to Equity Ratio, dan Firm Size Terhadap ...

sebagai gambaran untuk menilai kinerja keuangan perusahaan (Sefiani, 2016).

Laba atau profit merupakan salah satu tujuan utama berdirinya setiap badan usaha. Tanpa diperolehnya laba, perusahaan tidak dapat memenuhi tujuan lainnya yaitu pertumbuhan yang terus menerus dan tanggung jawab sosial.Laba yang menjadi tujuan utama perusahaan dapat dicapai dengan penjualan barang atau jasa. Semakin besar volume penjualan barang dan jasa, maka laba yang dihasilkan oleh perusahaan juga akan semakin besar. Kelangsungan hidup perusahaan dipengaruhi oleh banyak hal antara lain profitabilitas perusahaan itu sendiri (Alpi, 2018).

Pentingnya profitabilitas dapat dilihat dengan mempertimbangkan dampak yang berasal dari ketidak mampuan perusahaan dalam mendapatkan laba yang maksimal untuk mendukung kegiatan operasionalnya. Cara memperhitungkan profitabilitas adalah bermacammacam dan tergantung pada laba dan aktiva atau modal yang akan diperbandingkan satu dengan yang lainnya. Salah satu cara untuk menghitung profitabilitas adalah Return On Equity(Alpi, 2018). Return On Equity merupakan bagian dari rasio profitabilitas dalam menganalisa laporan keuangan atas laporan kinerja keuangan perusahaan. Menurut 
Brigham and Houston (2012) Return On Equity adalah pengembalian atas ekuitas biasa yaitu rasio laba bersih terhadap ekuitas biasa atau mengukur tingkat pengembalian atas investasi pemegang saham biasa. Dalam hal ini para pemegang saham mengharapkan peningkatan dalam pengembalian modal pemegang saham dan menarik investor baru untuk menginvestasikan dananya.

Sebuah perusahaan dalam menjalankan operasionalnya memerlukan biaya yang tidak sedikit jumlahnya.Biaya yang diperlukan tidak sepenuhnya dipenuhi dengan modal sendiri.Perusahaan perlu melakukan pinjaman kepada pihak kreditur dalam upaya pemenuhan kebutuhan biaya untuk kegiatan operasional perusahaan.Rasio yang digunakan untuk mengukur kemampuan perusahaan dalam memenuhi kewajiban jangka pendeknya adalah Current Ratio (CR).Current Ratio (CR) atau rasio lancar diperoleh dari perbandingan antara aktiva lancar dengan hutang lancar (Prihadi, 2012).Apabila presentase Current Ratiolancar dalam sebuah perusahaan rendah, maka dianggap terjadinya masalah dalam likuidasi. Dengan kata lain, perusahaan tidak memilki kemampuan dan kesempatan untuk memenuhi kewajiban jangka pendeknya. Sebaliknya, jika rasio lancar dalam perusahaan tinggi dikatakan baik bagi perusahaan tersebut.Hal ini dikarenakan, perusahaan 
Jufrizen \& Maya Sari : Pengaruh Current Ratio, Debt to Equity Ratio, dan Firm Size Terhadap ...

memiliki kemampuan untuk memenuhi kewajiban jangka pendeknya kepada pihak kreditur.Hasil penelitian Alpi (2018) menunjukkan bahwa Current Ratio berpengaruh signifikan terhadap Return On Equity.

Debt to Equity Ratio yaitu total kewajiban dibagi total ekuitas yang menunjukkan pengukur tingkat penggunaan utang (total hutang) terhadap modal yang dimiliki perusahaan (Riyanto, 2010). Dari perspektif kemampuan membayar kewajiban jangka panjang, semakin rendah rasio akan semakin baik kemampuan perusahaan dalam membayar kewajiban jangka panjang. Hasil penelitian Lokollo (2013) dan Rosyadah (2013) menyatakan bahwa Debt to Equity Ratio berpengaruh negatif terhadap Return On Equity, namun bertentangan dengan hasil penelitian Wahyuni (2017), Singapurwoko (2011) dan Mareta (2013) yang menyatakan bahwa Debt to Equity Ratio berpengaruh positif terhadap Return On Equity. Berbeda juga dengan penelitian Fachrudin (2007) dan Alpi (2018) yang menyatakan bahwa Debt to Equity Ratio tidak berpengaruh terhadap Return On Equity.

Ukuran perusahaan (firm size) adalah skala perusahaan yang dilihat dari total aktiva perusahaan pada akhir tahun. Total penjualan juga dapat digunakan untuk mengukur besarnya perusahaan. Karena biaya biaya yang mengikuti penjualan cenderung lebih besar, maka perusahaan 
dengan tingkat penjualan yang tinggi cenderung memilih kebijakan akuntansi yang mengurangi laba (Utama, 2000). Perusahaan yang memiliki banyak aset akan dapat meningkatkan kapasitas produksi yang berpotensi untuk menghasilkan laba lebih baik. Hasil penelitian Singapurwoko (2011) menyatakan bahwa ukuran perusahaan berpengaruh positif terhadap Return On Equity, namun bertentangan dengan hasil penelitian Kamaliah (2009) yang menyatakan bahwa ukuran perusahaan berpengaruh negatif terhadap ROE. Berbeda juga dengan penelitian Fachrudin (2007) yang menyatakan bahwa ukuran perusahaan tidak berpengaruh terhadap Return On Equity.

\section{TELAAH LITERATUR DAN PERUMUSAN HIPOTESIS}

\section{Return On Equity (ROE)}

Return On Equity yaitu rasio antara laba setelah pajak terhadap total modal sendiri (Equity) yang berasal dari setoran modal pemilik. Semakin tinggi Return On Equity menunjukkan semakin efisien perusahaan dalam mengelola modal sendiri untuk menghasilkan keuntungan/laba bersih. Rasio ini digunakan untuk mengukur tingkat pengembalian perusahaan atau efektivitas perusahaan dalam menghasilkan keuntungan dengan memanfaatkan ekuitas yang dimiliki 
Jufrizen \& Maya Sari : Pengaruh Current Ratio, Debt to Equity Ratio, dan Firm Size Terhadap ...

oleh perusahaan.Return On Equity merupakan bagian dari rasio profitabilitas dalam menganalisa laporan keuangan atas laporan kinerja keuangan perusahaan. Menurut Brigham and Houston (2012) "Return On Equity merupakan rasio laba bersih terhadap ekuitas biasa atau mengukur tingkat pengembalian atas investasi pemegang saham biasa. Return On Equity merupakan rasio yang digunakan untuk mengukur kemampuan dari modal sendiri untuk menghasilkan keuntungan bagi seluruh pemegang saham, baik saham biasa maupun saham preferen (Sujarweni, 2017).Return On Equity merupakan rasio yang menunjukkan seberapa besar kontribusi ekuitas dalam menciptakan laba bersih (Hery, 2016). Dengan kata lain, rasio ini digunakan untuk mengukur seberaa besar jumlah laba bersih yang akan dihasilkan dari setiaap rupiah dana yang tertanam dalam total ekuitas. Rasio ini dihitung dengan membagi laba bersih terhadap ekuitas. roe dipengaruhi oleh tiga faktor seperti yang dikemukakan oleh Hani (2015) adalah sebagai berikut : 1) volume penjualan, 2) struktur modal, 3) dan strukur utang. Adapun rumus untuk mencari Return On Equity menurut Kasmir (2014) adalah sebagai berikut:

Earning After Interest and Tax

Return On Equity =

Equity 
Hasil pengembalian ekuitas atau Return On Equity atau rentabilitas modal sendiri merupakan rasio untuk mengukur laba bersih dan modal sendiri. Semakin tinggi rasio ini, maka akan semakin baik. Artinya posisi pemilik perusahaan semakin kuat, demikian pula sebaliknya.

\section{Current Ratio (CR)}

Current Ratio merupakan rasio yang mengukur kemampuan perusahaan dalam memenuhi kewajiban jangka pendeknya yang segera jatuh tempo dengan menggunakan asset lancar yang tersedia (Hery, 2016). Dengan kata lain, rasio lancar ini menggambarkan seberapa besar jumlah ketersediaan asset lancar yang dimiliki perusahaan dibandingkan dengan total kewajiban lancar. Oleh sebab itu, rasio lancar dihitung sebagai hasil bagi antara total asset lancar dengan total kewajiban lancar.Current Ratio merupakan Rasio yang digunakan untuk mengukur kemampuan perusahaan dalam membayar membayar kewajiban jangka pendeknya dengan menggunakan aktiva lancar yang dimiliki (Sujarweni, 2017).Current Ratio merupakan rasio untuk mengukur kemampuan perusahaan membayar kewajiban jangka pendek atau utang yang segera jatuh tempo pada saat ditagih secara keseluruhan. Dengan kata lain, seberapa banyak aktiva lancar yang tersedia untuk menutupi kewajiban 
Jufrizen \& Maya Sari : Pengaruh Current Ratio, Debt to Equity Ratio, dan Firm Size Terhadap ...

jangka pendek yang segera jatuh tempo. Rasio lancar dapat pula dikatakan sebagai bentuk untuk mengukur tingkat keamanan (margin of safety) suatu perusahaan (Kasmir, 2014).Current Ratiolancar dihitung dengan membagi aktiva lancar dengan hutang lancar.Rasio ini menunjukan besarnya kas yang dipunyai perusahaan ditambah asetaset yang bisa berubah menjadi kas dalam waktu satu tahun, relatif terhadap besarnya hutang-hutang yang jatuh tempo dalam jangka waktu dekat (tidak lebih dari 1 tahun), pada tanggal tertentu seperti tercantum pada neraca (Hanafi dan Halim, 2012).

Berdasarkan beberapa definisi di atas, dapat disimpulkan bahwa Current Ratio merupakan rasio untuk mengukur likuiditas perusahaan dalam membayar hutang jangka pendek dengan aset lancar yang dimiliki perusahaan.

Berikut ini adalah tujuan dan manfaat yang dapat dipetik dari hasil rasio likuiditas (Hery, 2016), yaitu :

1) Untuk mengukur kemampuan perusahaan membayar kewajiban atau utang yang segera jatuh tempo pada saat ditagih. Artinya, kemampuan untuk membayar kewajiban yang sudah waktunya dibayar sesuai jadwal batas waktu yang telah ditetapkan (tanggal dan bulan tertentu).

2) Untuk mengukur kemampuan perusahaan dalam membayar kewajiban jangka pendek dengan menggunakan total asset lancar. 
3) Untuk mengukur kemampuan perusahaan dalam membayar kewajiban jangka pendek dengan menggunakan asset sangat lancar (tanpa menghitung persediaan barang dagang dan asset lancar lainnya).

4) Untuk mengukur tingkat ketersediaan uangn kas perusahaan dalam membayar utang jangka pendek.

5) Sebagai alat perencanaan keuangan di masa mendatang terutama yang berkaitan dengan perencanaan kas dan utang jangka pendek.

Likuiditas merupakan kemampuan perusahaan dalam memenuhi kewajiban jangka pendeknya.Tingkat likuiditas perusahaan dapat diukur dengan membandingkan jumlah aktiva lancar dengan kewajiban lancar yang dimiliki perusahaan. Semakin tinggi tingkat likuiditas maka semakin baik bagi perusahaan. Ketidakmampuan perusahaan membayar kewajibannya terutama utang jangka pendek (yang sudah jatuh tempo) disebabkan oleh berbagai faktor:1) bisa dikarenakan memang perusahaan sedang tidak memiliki dana sama sekali, dan 2) bisa mungkin saja perusahaan memiliki dana, namun saat jatuh tempo perusahaan tidak memiliki dana (tidak cukup) secara tunai sehingga harus menunggu dalam waktu tertentu, untuk mencairkan aktiva lainnya seperti menagih piutang, menjual surat-surat berharga, atau menjual sediaan atau aktiva lainnya (Kasmir, 2014). 
Jufrizen \& Maya Sari : Pengaruh Current Ratio, Debt to Equity Ratio, dan Firm Size Terhadap ...

\section{Debt to Equity Ratio}

Debt to Equity Ratio merupkan rasio yang digunakan untuk mengukur besarnya proporsi utang terhadap modal. Rasio ini dihitung sebagai hasil bagi antara total utang dengan modal. Rasio ini berguna untuk mengetahui besarnya perbandingan antara jumlah dana yang disediakan oleh kreditor dengan jumlah dana yang berasal dari pemilik perusahaan (Hery, 2016). Dengan kata lain, rasio ini berfungsi untuk mengetahui berapa bagian dari setiap rupiah modal yang dijadikan sebagai jaminan utang. Rasio ini memberikan petunjuk umum tentang kelayakan kredit dan resiko keuangan debitor.Debt to Equity Ratio merupakan salah satu rasio leverage atau solvabilitas. Rasio solvabilitas adalah rasio untuk mengetahui kemampuan perusahaan dalam membayar kewajiban jika perusahaan tersebut dilikuidasi.Rasio ini juga disebut dengan rasio pengungkit (Leverage) yaitu menilai batasan perusahaan dalam meminjam uang (Darsono dan Ashari, 2010).

Debt to Equity Ratio merupakan rasio yang menggambarkan kemampuan perusahaan dalam membayar kewajiban-kewajibannya apabila perusahaan likuidasi.Rasio ini dapat dihitung dari pos-pos yang sifatnya jangka panjang seperti aktiva tetap dan utang jangka panjang (Harahap, 2017). Horne dan Machowicz (2009) mengemukakan bahwa "leverage merupakan penggunaan biaya tetap dalam usaha untuk meningkatkan (level up) profitabilitas.Siegel dan Shim dalam Fahmi (2014) Debt to Equity Ratio merupakan Ukuran yang dipakai dalam menganalisis laporan keuangan untuk memperlihatkan besarnya jaminan 
yang tersedia untuk kreditor.Debt to Equity ratio merupakan rasio yang digunakan untuk menilai hutang dengan ekuitas. Rasio ini dicari dengan cara membandingkan antara seluruh hutang, termasuk hutang lancar dengan seluruh ekuitas. Rasio ini digunakan untuk mengetahui jumlah dana yang disediakan peminjam (kredior) dengan pemilik perusahaan. Dengan kata lain, rasio ini berfungsi untuk mengetahui setiap rupiah modal sendiri yang dijadikan untuk jaminan hutang (Kasmir, 2014).

\section{Ukuran Perusahaan (Firm Size)}

Perusahaan besar yang sudah wellestablished akan lebih mudah memperoleh modal di pasar modal dibanding dengan perusahaan kecil. Karena kemudahan akses tersebut berarti perusahaan besar memiliki fleksibilitas yang lebih besar pula (Sartono, 2010).Semakin baik kualitas laporan keuangan yang disajikan maka akan semakin menyakinkan pihak eksternal dalam melihat kinerja keuangan perusahaan tersebut, yang otomatis tentunya pihak-pihak yang berhubungan dengan perusahaan akan merasa puas dalam berbagai urusan dengan perusahaan (Fahmi, 2014). Perusahaan selalu menginginkan perolehan laba bersih setelah pajak karena bersifat menambah modal sendiri. Dengan kata lain, laba bersih dapat diperoleh jika jumlah penjualan lebih besar daripada jumlah biaya operasi. Agar diperoleh laba bersih yang sesuai dengan jumlah yang 
diinginkan, maka perencanaan dan pengendalian menjadi hal yang sangat penting dilakukan oleh pihak manajemen.Perusahaan yang berada pada pertumbuhan penjualan yang tinggi membutuhkan dukungan modal yang semakin besar, demikian juga sebaliknya, pada perusahaan yang tingkat pertumbuhan penjualannya rendah kebutuhan terhadap modal juga semakin kecil. Akan tetapi, jika dana dari sumber intern sudah tidak mencukupi, maka tidak ada pilihan lain bagi perusahaan untuk menggunakan dana yang berasal dari luar perusahaan, baik utang maupun dengan mengeluarkan saham baru. Perusahaan yang besar cenderung memiliki sumber permodalan yang lebih banyak dan memiliki kemungkinan untuk bangkrut yang lebih kecil, sehingga lebih mampu untuk memenuhi kewajiban finansialnya. Dengan kata lain, perusahaan besar cenderung memiliki utang atau menggunakan dana eksternal dalam jumlah yang lebih besar. Suatu perusahaan yang besar yang sahamnya tersebar sangat luas, setiap perluasan modal saham hanya akan mempunyai pengaruh yang kecil terhadap kemungkinan hilangnya atau tergesernya pengendalian dari pihak yang dominan terhadap perusahaan bersangkutan. Dengan demikian, maka perusahaan yang besar akan lebih berani mengeluarkan saham baru dalam memenuhi kebutuhan untuk 
membiayai pertumbuhan yang didasarkan pada penjualan, dibandingkan dengan perusahaan yang kecil (Riyanto, 2010).

\section{Perumusan Hipotesis}

\section{Pengaruh Current Ratio terhadap Return On Equity}

Untuk menjalankan operasional dalam perusahaan dibutuhkan dana yang cukup besar. Kebutuhan dana ini tidak dapat sepenuhnya dipenuhi dengan menggunakan modal yang dimiliki perusahaan. Hutang merupakan pelengkap kebutuhan dana operasional perusahaan dimana adanya kekurangan dana dalam menjalankan kegiatan operasional perusahaan. Perusahaan yang mampu mengelola hutang secara efektif akan meringankan kewajibannya untuk membayar hutang jangka pendek yang telah dijatuh tempokan.Current Ratioatau Rasio Lancar merupakan rasio untuk mengukur kemampuan perusahaan dalam membayar kewajiban jangka pendek atau utang yang segera jatuh tempo pada saat ditagih sacara keseluruhan. Dengan kata lain, seberapa banyak aktiva lancar yang tersedia untuk menutupi kewajiban jangka pendek yang segera jatuh tempo (Kasmir, 2010). Hasil penelitian Alpi (2018) dan Wahyuni (2017) menunjukkan bahwa Current Ratio berpengaruh signifikan terhadap profitabilitas Return On Equity.Selanjutnya penelitian 
Ardiatmi (2014) menunjukkan semakin tinggi likuiditas perusahaan, semakin rendah profitabilitasnya. Artinya likuiditas Current Ratio berpengaruh signifikan terhadap Return On Equity.Berdasarkan uraian diatas dapat disimpulkan bahwa Current Ratio adalah rasio untuk mengukur kemampuan perusahaan dalam membayar hutang jangka pendeknya. Apabila Current Ratio perusahaan mengalami kenaikan maka profitabilitas perusahaan akan menurun.

H1 : Current Ratioberpengaruh terhadap Return On Equity

\section{Pengaruh Debt to Equity Ratio Terhadap Return On Equity}

Tinggi rendahnya Debt to Equity Ratioakan mempengaruhi tingkat pencapaian Return On Equity yang dicapai perusahaan. Jika biaya yang ditimbulkan oleh pinjaman lebih kecil dari pada biaya modal sendiri, maka sumber dana yang berasal dari pinjaman atau hutang akan lebih efektif dalaam menghasilkan laba.Kasmir (2010) dalam praktiknya, menyatakan apabila dari hasil perhitungan perusahaan ternyata memiliki rasio solvabilitas yang tinggi, hal ini akan berdampak timbulnya risiko kerugian lebih besar, tetapi juga ada kesempatan mendapat laba besar juga. sebaliknya apabila perusahaan memiliki rasio solvabilitas lebih rendah tentu mempunyai resiko kerugian lebih kecil pula, terutama saat 
perekonomian menurun. Dampak ini juga mengakibatkan rendahnya hasil pengembalian (return) pada saat perekonomian tinggi.Dari hasil penelitian Wahyuni (2017) bahwa Debt to Equity Ratioberpengaruh signifikan terhadap Return On Equity.Berdasarkan uraian di atas disimpulkan, tingginya rasio solvabilitas pada perusahaan, maka perusahaan akan mengalami penurunan pada profitabilitasnya. Ini dapat menyebabkan jumlah keuntungan yang diperoleh akan digunakan untuk membayar beban bunga atas pinjaman yang dilakukan perusahaan dalam menambah kebutuhan dana operasionalnya.

H2 : Debt to Equity Ratio berpengaruh terhadap Return On Equity

\section{Pengaruh Ukuran Perusahaan Terhadap Return On Equity}

Ukuran perusahaan dapat dilihat dari aset yang dimiliki oleh perusahaan.Apabila suatu perusahaan asetnya lebih besar dari aset perusahaan lainnya artinya perusahaan tersebut kapasitas produksinya lebih besar. Maka akan lebih berpotensi mendapatkan keuntungan yang lebih baik dan sejumlah asetnya akan maksimum dalam memenuhi permintaan (Singapurwoko, 2011). Ukuran perusahaan yang tercermin dari asetnya yang banyak dan tersebar dapat berpengaruh terhadap kemampuan perusahaan dalam menghasilkan laba dalam dua arah.Jika 
Jufrizen \& Maya Sari : Pengaruh Current Ratio, Debt to Equity Ratio, dan Firm Size Terhadap ...

kondisi ekonomi stabil, tidak ada gejolak dan semua kondisi ideal dengan manajemen yang dapat memanfaatkan asetnya, maka profit dapat meningkat. Namun pada saat krisis, dalam sebagian besar perusahaan yang berukuran besar justru profit mengalami penurunan. Hal ini dapat terjadi karena biaya operasional perusahaan berukuran besar jauh lebih besar daripada biaya operasional perusahaan kecil, sehingga dengan adanya krisis, asset yang besar tersebut justru membebani perusahaan sehingga menurunkan tingkat profitabilitas perusahaan (Riccardo, 2012 dalam Ardiatmi, 2014 ).

Hasil penelitian Kamaliah (2009) berkesimpulan bahwa ukuran perusahaan berpengaruh negatif terhadap Return On Equity, namun bertentangan dengan hasil penelitian Singapurwoko (2011) yang menyatakan bahwa ukuran perusahaan berpengaruh positif terhadap Return On Equity. Penelitian Fachrudin (2007) yang menyatakan bahwa ukuran perusahaan tidak berpengaruh terhadap Return On Equity. Sehingga berdasarkan uraian di atas dapat disimpulkan bahwa Size berpengaruh pada profitabilitas.

H3 : Firm Size berpengaruh terhadap Return On Equity 


\section{METODE PENELITIAN}

Pendekatan penelitian yang digunakan dalam penelitian ini adalah dengan menggunakan pendekatan asosiatif. Populasi dalam penelitian ini adalah seluruh Perusahaan Subsektor Pertanian yang terdaftar di Bursa Efek Indonesia (BEI) yang berjumlah 14 Perusahaan, sedangkan sampel yang memenuhi kriteria dalam penarikan sampel untuk penelitian ini adalah berjumlah 6 Perusahaan Subsektor Pertanian yang terdaftar di Bursa Efek Indonesia (BEI) periode tahun 2011 - 2016. Teknik pengumpulan data yang dilakukan adalah dengan menggunakan studi dokumentasi.Analisis data sampel yang digunakan dalam penelitian ini adalah Regresi Linier Berganda.

\section{HASIL DAN PEMBAHASAN}

\section{Uji Asumsi Klasik}

Uji asumsi klasik merupakan persyaratan analisis regresi berganda.Yang bertujuan untuk memperoleh hasil analisis yang valid.Dalam uji asumsi klasik ini meliputi uji normalitas, uji multikolinearitas, uji heterokedastisitas, dan uji autokolerasi.

\section{a. Uji Normalitas}

Uji normalitas bertujuan apakah regresi, variabel dependen dan variabel independen Uji normalitas dilakukan untuk melihat apakah dalam model regresi 
variabel dependen dan independen memiliki distribusi yang normal atau tidak. Untuk menguji nomalitas data pada penelitian ini adalah sebagai berikut :

Gambar 1.

Hasil Uji Normalitas P-P Plot

Normal P-P Plot of Regression Standardized Residual

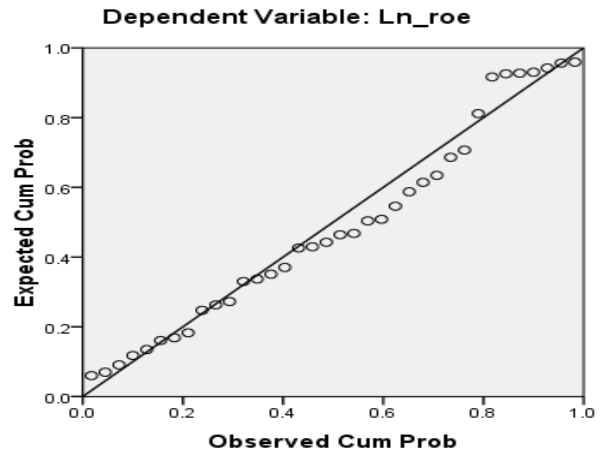

Sumber : Hasil Pengolahan Data (2018)

Berdasarkan gambar diatas dapat dilihat bahwa titik-titik menyebar mengikuti gari diagonal, oleh karena itu uji normalitas data dengan menggunakan P-Plot of Regression Standardized Residual di atas, dapat dinyatakan bahwa data tersebut berdistribusi normal dan sudah memenuhi asumsi normalitas.

\section{b. Uji Multikolinearitas}

Uji multikolineritas digunakan untik mengetahui apakah dalam model regresi ditemukan adanya korelasi yang tinggi diantara variabel bebas, dengan ketentuan :

1) Bila Tolerance $<0,10$ atau sama dengan VIF $>10$ maka terdapat masalah multikolinearitas yang serius 
2) Bila Tolerance $>0,10$ atau sama dengan VIF $<10$ maka tidak terdapat masalah multikolineritas yang serius.

Tabel 1.

Hasil Uji Multikolinearitas

Coefficients ${ }^{a}$

\begin{tabular}{|ll|r|r|}
\hline \multicolumn{2}{|l|}{ Model } & \multicolumn{2}{|c|}{ Collinearity Statistics } \\
\cline { 3 - 4 } & & Tolerance & \multicolumn{2}{|c|}{ VIF } \\
\hline \multirow{3}{*}{1} & (Constant) & .698 & 1.434 \\
& LN_CR & .673 & 1.486 \\
& LN_DER & .950 & 1.053 \\
\hline
\end{tabular}

a. Dependent Variable: LN_ROE

Sumber : Hasil Pengolahan (2018)

Berdasarkan tabel diatas ketiga variabel independen yakni Current Ratio, Debt to Equity Ratio dan firm size memiliki nilai Tolerance $>0,10$ atau sama dengan VIF $<10$, sehingga tidak terjadi multikolinearitas dalam variabel independen penelitian ini.

\section{c. Uji Heterokedastisitas}

Uji Heterokedastisitasdilakukan untuk mengetahui apakah dalam model sebuah regresi terjadi ketidaksamaan varians dari residual satu pengamatan ke pengamatan yang lain. Untuk mengetahui apakah terjadi satu pengamatan ke pengamatan yang lain. Untuk mengetahui apakah terjadi heterokedastisitas dalam model regresi penelitian ini, analisis yang dilakukan adalah dengan metode informal.Metode informal dlam 
Jufrizen \& Maya Sari : Pengaruh Current Ratio, Debt to Equity Ratio, dan Firm Size Terhadap ...

pengujian heterokedastisitas yakni metode grafik dan metode Scatterplot. Dasar Analisis:

1) Jika ada pola tertentu, seperti titik-titik membentuk suatu pola yang teratur, maka telah terjadi heterokedastisitas.

2) Jika tidak terjadi pola yang jelas serta titik-titik menyebar tidak teratur maka tidak terjadi heterokedastisitas

Gambar 2.

Hasil Uji Heterokedastisitas

Scatterplot

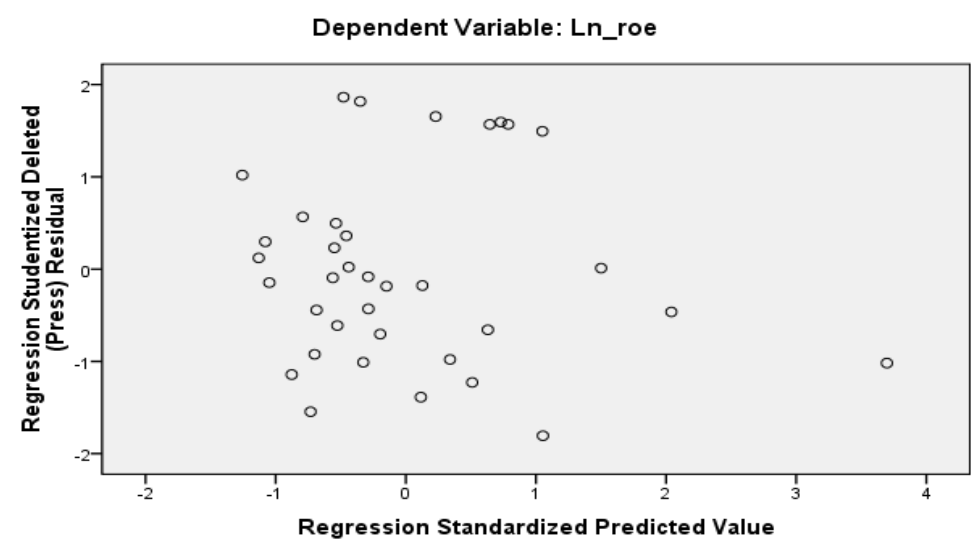

Sumber : Hasil Pengolahan Data (2018)

Gambar diatas memperlihatkan titik-titik menyebar secara acak, tidak membentuk pola yang jelas/teratur, serta tersebar baik diatas maupun dibawah angka 0 pada sumbu Y. dengan demikian "tidak terjadi heterokedastisitas" pada model regresi.

\section{Pengujian Hipotesis}


Dalam menganalisis data digunakan analisis regresi linear berganda.Dimana analisis berganda berguna untuk mengetahui pengaruh dari masing-masing variabel bebas terhadap variabel terikat.Berikut hasil pengolahan data dengan menggunakan SPSS versi 16.00 .

Tabel 2

Hasil Uji Regresi Linear Berganda Coefficients $^{\mathrm{a}}$

\begin{tabular}{|l|r|r|r|r|r|}
\hline \multirow{2}{*}{ Model } & \multicolumn{2}{|c|}{$\begin{array}{c}\text { Unstandardized } \\
\text { Coefficients }\end{array}$} & $\begin{array}{c}\text { Standardiz } \\
\text { ed } \\
\text { Coefficient } \\
\mathrm{s}\end{array}$ & \multicolumn{1}{|c|}{$\mathrm{t}$} & \multirow{2}{*}{ Sig. } \\
\cline { 2 - 4 } & $\mathrm{B}$ & $\begin{array}{c}\text { Std. } \\
\text { Error }\end{array}$ & \multicolumn{1}{|c|}{ Beta } & & \\
\hline (Constant & -.691 & 1.290 & & -.535 & .596 \\
LN_CR & -.142 & .255 & -.115 & -.558 & .581 \\
LN_CDR & .151 & .437 & .072 & .346 & .732 \\
SIZE & -.083 & .080 & -.183 & -1.041 & .306 \\
\hline
\end{tabular}

a. Dependent Variable: LN_ROE

Sumber : Hasil Pengolahan Data (2018)

Dalam penelitian ini digunakan analisis regresi digunakan untuk menguji hipotesis. Untuk tujuan ini, digunakan nilai signifikansi (sig). Untuk nilai hubungan yang signifikan harus kurang dari 0,05 (sig $\leq 0,05$ ). Tabel 2 menunjukkan bahwa Current Ratio tidak memiliki pengaruh yang signifikan terhadap Return On Equitydengan sig 0,581. Nilai beta $-0,142$ menunjukkan pengaruh yang negatif.Oleh karena itu, $\mathrm{H} 1$ ditolak. Demikian pula, pengaruh Debt to Equity ratio terhadap Return On Equity 
dengan sig 0,581juga tidak signifikan dengan sig 0,732 , sedangkan nilai beta 0,151 menunjukkan pengaruh yang positif. Selanjutnya firm size juga tidak memiliki pengaruh yang signifikan terhadap terhadap Return On Equity dengan sig 0,306. Nilai beta $-0,083$ menunjukkan pengaruh yang negatif.Oleh karena itu, $\mathrm{H} 2$ dan $\mathrm{H} 3$ juga ditolak. Ini menunjukkan bahwa Current Ratio, Debt to Equity Ratio dan firm size tidak dapat meningkatkan Return On Equity pada Perusahaan Perkebunan yang terdaftar di Bursa Efek Indonesia periode 2011-2016.

\section{PEMBAHASAN}

\section{Pengaruh Current Ratio terhadap Return On Equity}

Berdasarkan hasil penelitian mengenai Current Ratio terhadap Return On Equitypada Perusahaan Perkebuanan yang terdaftar di Bursa Efek Indonesia menyatakan bahwa Current Ratiotidak berpengaruh signifikan Ratio terhadap Return On Equity pada Perusahaan Perkebunan yang terdaftar di Bursa Efek Indonesia periode 2011-2016.

Current Ratiomerupakan ukuran perusahaan dalam memenuhi kewajiban jangka pendek.Rasio ini merupakan rasio likuiditas.Current Ratioyang rendah biasanya dianggap menunjukkan terjadinya masalah dalam likuidasi, sebaliknya Current Ratioyang terlalu tinggi juga kurang 
bagus, karena menunjukkan banyaknya dana menganggur yang pada akhirnya dapat mengurangi kemampu labaan perusahaan (Sawir, 2009). Peningkatan Current Ratio berbanding terbalik dengan ukuran profitabilitas perusahaan.Tingkat likuiditas perusahaan yang baik dapat berarti bahwa penurunan laba.Hal ini dapat terjadi karena laba operasi banyak dipergunakan untuk melakukan pembayaran hutang jangka pendeknya. Hal ini berakibat pada adanya penurunan laba dan penurunan dari hutang jangka pendek, sehingga mengakibatkan likuiditas meningkat dan tingkat profitabilitas menjadi menurun (Riccardo, 2012 dalam Ardiatmi, 2014 ).

Berdasarkan hasil penelitaian yang dilakukan penulis serta teori, pendapat, maupun penelitian terdahulu yang telah dikemukakan diatas mengenai pengaruh Current Ratio terhadap profitabilitas (ROE) perusahaan. Maka penulis dapat menyimpulkan bahwa Current Ratio berpengaruh negatif dan tidak signifikan terhadap Return On Equity. Hasil penelitian ini didukung atau sejalan dengan penelitian yang dilakukan oleh Bolek (2012) dan Lokollo (2013) yang menyatakan bahwa Current Ratio berpengaruh negatif terhadap Return On Equity. Selanjutnya penelitian Bolek (2013) dan Nugroho (2012) menunjukkan bahwa Current Ratio tidak berpengaruh signifikan terhadap Return On Equity. 
Hasil penelitian yang dilakukan oleh Alpi (2018), Wahyuni (2017) dan Murtizanah (2012) yang berkesimpulan bahwa Current Ratio berpengaruh positif dan signifikan terhadap Return On Equity.

\section{Pengaruh Debt to Equity Ratio terhadap Return On Equity}

Berdasarkan hasil penelitian mengenai Debt to Equity Ratio terhadap Return On Equitypada Perusahaan Perkebunan yang terdaftar di Bursa Efek Indonesia menunjukkan bahwa Debt to Equity Ratio tidak berpengaruh signifikan terhadap Return On Equity pada Perusahaan Perkebunan yang terdaftar di Bursa Efek Indonesia periode 2011-2016.

Debt to Equity Ratio merupakan rasio yang menggambarkan kemampuan perusahaan dalam membayar kewajiban-kewajibannya apabila perusahaan likuidasi.Rasio ini dapat dihitung dari pos-pos yang sifatnya jangka panjang seperti aktiva tetap dan utang jangka panjang (Harahap, 2017).DER menggambarkan kemampuan perusahaan dalam mengcover pembayaran hutang jangka panjang dengan menggunakan modal sendiri atau ekuitas dari shareholders sebagai leveragenya.Rasio DER yang tinggi dapat menggambarkan bahwa perusahaan dapat beroperasi dengan hutang sebagai modalnya. Hutang usaha ini jika dipergunakan secara tepat akan dapat menghasilkan profit yang semakin 
meningkat pula bila dibandingkan dengan operasional dengan modalnya sendiri (Riccardo, 2012 dalam Ardiatmi, 2014 ).

Berdasarkan hasil penelitaian yang dilakukan penulis serta teori, pendapat, maupun penelitian terdahulu yang telah dikemukakan diatas mengenai pengaruh Debt to Equity Ratio terhadap Return On Equityperusahaan. Maka penulis dapat menyimpulkan bahwa Debt to Equity Ratio berpengaruh positif dan tidak signifikan terhadap Return On Equityperusahaan. Hasil penelitian ini didukung atau sejalan dengan penelitian Fachrudin (2007) dan Alpi (2018) yang menyatakan bahwa Debt to Equity Ratio tidak berpengaruh signifikan terhadap Return On Equity. Sementara itu hasil penelitian Wahyuni (2017), Singapurwoko (2011), Mareta (2013) dan Kamallah (2009) menunjukkan bahwa DER berpengaruh positifterhadap $\mathrm{ROE}$, namun bertentangan dengan hasil Lokollo (2013) dan Rosyahdah (2013) yang menyatakan bahwa Debt to Equity Ratio berpengaruh negatif terhadap Return On Equity.

\section{Pengaruh Firm Size Perusahaan terhadap Return On Equity}

Berdasarkan hasil penelitian mengenai Ukuran Perusahaan terhadap Return On Equity pada Perusahaan Perkebunan yang terdaftar di Bursa Efek Indonesia menunjukkan bahwa Ukuran Perusahaan tidak 
Jufrizen \& Maya Sari : Pengaruh Current Ratio, Debt to Equity Ratio, dan Firm Size Terhadap ...

berpengaruh signifikan terhadap Return On Equity Perusahaan Perkebunan yang terdaftar di Bursa Efek Indonesia periode 2011-2016.

Menurut Riyanto (2010), suatu perusahaan yang besar yang sahamnya tersebar sangat luas, setiap perluasan modal saham hanya akan mempunyai pengaruh yang kecil terhadap kemungkinan hilangnya atau tergesernya pengendalian dari pihak yang dominan terhadap perusahaan bersangkutan. Dengan demikian, maka perusahaan yang besar akan lebih berani mengeluarkan saham baru dalam memenuhi kebutuhan untuk membiayai pertumbuhan yang didasarkan pada penjualan, dibandingkan dengan perusahaan yang kecil. Ukuran perusahaan yang tercermin dari asetnya yang banyak dan tersebar dapat berpengaruh terhadap kemampuan perusahaan dalam menghasilkan laba dalam dua arah.Jika kondisi ekonomi stabil, tidak ada gejolak dan semua kondisi ideal dengan manajemen yang dapat memanfaatkan asetnya, maka profit dapat meningkat. Namun pada saat krisis, dalam sebagian besar perusahaan yang berukuran besar justru profit mengalami penurunan. Hal ini dapat terjadi karena biaya operasional perusahaan berukuran besar jauh lebih besar daripada biaya operasional perusahaan kecil, sehingga dengan adanya krisis, asset yang besar tersebut justru 
membebani perusahaan sehingga menurunkan tingkat profitabilitas perusahaan (Riccardo, 2012 dalam Ardiatmi, 2014 ).

Berdasarkan hasil penelitaian yang dilakukan penulis serta teori, pendapat, maupun penelitian terdahulu yang telah dikemukakan diatas mengenai pengaruh Ukuran Perusahaan terhadap Return On Equityperusahaan. Maka penulis dapat menyimpulkan bahwa Ukuran Perusahaan berpengaruh negatif dan tidak signifikan terhadap Return On Equityperusahaan. Hasil penelitian ini didukung atau sejalan dengan penelitian Kamaliah (2009) yang menyatakan bahwa ukuran perusahaan berpengaruh negatif terhadap Return On Equity, namun bertentangan dengan hasil penelitian Singapurwoko (2011) yang menyatakan bahwa ukuran perusahaan berpengaruh positif terhadap Return On Equitydan Penelitian Fachrudin (2007) yang menyatakan Ukuran Perusahaan tidak berpengaruh terhadap Return On Equity.

\section{SIMPULAN}

Berdasarkan hasil penelitian dan pembahasan yang telah dikemukakan sebelumnya maka dapat diambil kesimpulan dari penelitian mengenai Pengaruh Current Rasio, Debt to Equity Ratio dan Firm Size terhadap Return On Equity pada perusahaan Perkebunan yang terdaftar 
di Bursa Efek Indonesia periode 2011-2016 dengan sampel 6 perusahaan adalah sebagai berikut :

1. Secara Persial, bahwa, Current Rtio (CR) memiliki pengaruh negatif dan tidak signifikan terhadap Return On Equity(ROE) pada Perusahaan Perkebunan yang terdaftar di Bursa Efek Indonesia Periode 2011-2016.

2. Secara Persial, bahwa, Debt to Equity Rtio (DER) memiliki pengaruh positif dan tidak signifikan terhadap Return On Equity(ROE) pada Perusahaan Perkebunan yang terdaftar di Bursa Efek Indonesia Periode 2011-2016.

3. Secara Persial, bahwa, Ukuran Perusahaan (Firm Size) memiliki pengaruh negatif dan tidak signifikan terhadap Return On Equity(ROE) pada Perusahaan Perkebunan yang terdaftar di Bursa Efek Indonesia Periode 2011-2016.

Berdasarkan hasil penelitian tersebut dapat dikemukakan implikasi secara teoritis dan praktis sebagai berikut:

1. Implikasi Teoritis

ROE dapat memberikan gambaran seberapa efisien perusahaan dalam mengelola ekuitasnya untuk menghasilkan laba bersih perusahaan.Semakin tinggi nilai ROE, maka menunjukkan bahwa perusahaan telah efektif dalam menggunakan ekuitasnya, yang memiliki dampak untuk menghasilkan keuntungan yang maksimal bagi perusahaan. Naiknya rasio ROE dari tahun ke tahun mengindikasikan terjadi adanya kenaikan laba bersih dari perusahaan 
yang bersangkutan. Naiknya laba bersih pada sebuah perusahaan dapat menjadi indikasi naiknya nilai perusahaan karena bila terjadi peningkatan laba bersih maka akan diikuti dengan naiknya harga saham, dengan begitu nilai perusahaan juga akan meningkat karena adanya kenaikan pada harga saham.

\section{Implikasi Praktis}

Hasil penelitian ini diharapkan dapat menjadi acuan bagi calon investor dalam pengambilan keputusan untuk berinvestasi di suatu perusahaan. Calon Investor dapat mempertimbangkan faktor-faktor yang mempengaruhi profitabilitas (ROE) perusahaan ketika akan berinvestasi.

Penelitian ini dilakukan dengan beberapa keterbatasan penelitian yang dengan keterbatasan tersebut dapat berpengaruh terhadap hasil penelitian. Keterbatasan penelitian ini yaitu :

a. Penelitian ini hanya menggunakan perusahaan manufaktur yang terdaftar di Bursa Efek Indonesia selama tahun 2011-2016 sebagai sampel sehingga belum dapat merepresentasikan semua perusahaan yang ada.

b. Penelitian ini hanya menggunakan ROE sebagai proksi dari kinerja keuangan perusahaan.

Berdasarkan hasil penelitian ini terdapat beberapa saran untuk perbaikan penelitian kedepanya sebagai berikut: 
a. Menambah jumlah sampel penelitian dengan mamanjangkan periode waktu penelitian agar hasil penelitian dapat lebih mencerminkan kondisi yang sesungguhnya.

b. Penelitian selanjutnya dapat menggunakan proksi kinerja keuangan yang lain, seperti ROA, NPM, PBV, atau leverage.

c. Penelitian selanjutnya sebaiknya dilakukan penambahan variabel-variabel lain yang diluar model penelitian yang diperkirakan berpengaruh terhadap Return On Equity.

\section{DAFTAR PUSTAKA}

Ardiatmi, U. D. (2014). Analisis Pengaruh Current Ratio, Debt to Equity Ratio, Total Asset Turn Over, Firm Size dan Debt to Asset Ratio terhadap Profitabilitas (ROE). Skripsi. Fakultas Ekonomika dan Bisnis Universitas Diponegoro Semarang.

Bolek, Monika. (2013). Profitability as a Liquidity and Risk Function Basing on The New Connect Market in Poland. European Scientific Journal, 9 (28).

Brigham E.F, \&Houston J, F. (2012).Dasar-dasar Manajemen Keuangan, (Edisi 11) Jakarta : Salemba Empat.

Brigham, Eugene F. dan Joe F Houston.(2010). Dasar-dasar Manajemen Keuangan, Jakarta : Salemba Empat. 
Darsono dan Ashari.(2010). Pedoma Praktis Memahami Laporan Keuangan (Tips Bagi Investor.Direksi, dan Pemegang Saham). Penerbit Andi. Yogyakarta

Murtizanah, D.I (2013), Analisis Pengaruh Rasio Likuiditas Dan Rasioaktivitas Terhadap Profitabilitas KPRI "Makmur" Krian, Jurnal Pendidikan Ekonomi (JUPE), 1 (3) ; 1-20

Fachrudin, K.A. (2011). Analisis Pengaruh Struktur Modal, Ukuran Perusahaan, dan Agency Cost terhadap Kinerja Perusahaan.Jurnal Akuntansi dan Keuangan, 13 (1).

Fahmi, I. (2014). Analisis Laporan Keuangan. Edisi Ketiga. CV Alfabeta. Bandung.

Hanafi, dan Halim.A (2012).Analisis Laporan Keuangan, Edisi ke 4 Unit penerbit dan percetakan sekolah tinggi ilmu manajemen YKPN. Yogyakarta.

Hani, S. (2015).Teknik Analisa Laporan Keuangan. Medan : Penertbit Umsu Press.

Harahap, S. S. (2017). Analisis Kritis atas Laporan Keuangan, Cetakan Kedua belas.Jakarta : PT. Raja Grafindo Persada

Harahap, S. S. (2015). Analisis Kritis atas Laporan Keuangan.PT Raja Grafindo Persada. Jakarta.

Hery.(2016). Analisis Laporan Keuangan. Cetakan Pertama. Jakarta: PT Gramedia 
Jufrizen \& Maya Sari : Pengaruh Current Ratio, Debt to Equity Ratio, dan Firm Size Terhadap ...

Horne, J. C. Van dan Wachowicz, JR. J.M.(2009).Prinsip-prinsip Manajemen Keuangan., Jakarta : Salemba Empat.

Juliandi, A, Irfan and Manurung. S. (2015).Metodologi Penelitian Bisnis Konsep dan Aplikasi.Medan : UMSU Press

Kamaliah, A. N, dan Kinanti.L. (2009). Analisis Pengaruh Rasio Aktivitas, Leverage Keuangan, Ukuran, dan Umur Perusahaan Terhadap Profitabilitas Perusahaan Wholesale and Retail Trade yang Terdaftar di Bursa Efek Indonesia. Jurnal Ekonomi. Universitas Riau.

Kasmir.(2010). Pengantar Manajemen Keuangan. Jakarta: Kencana

Kasmir.(2014). Analisis Laporan Keuangan.PT Raja Grafindo Persada. Jakarta

Lokollo, A, (2013), Pengaruh Manajemen Modal Kerja Dan Rasio Keuangan Terhadap Profitabilitas Pada Industri Manufaktur Yang Terdaftar di Bursa Efek Indonesia (BEI) Tahun 2011, Journal of Accounting, $2(2): 1-13$

Alpi, M.F. (2018), Pengaruh Debt to Equity Ratio, Inventory Turn Over, Dan Current Ratio Terhadap Return On Equity Pada Perusahaan Sektor Farmasi Yang Terdaftar Di Bursa Efek Indonesia, Prosiding: The National Conferences Management and Business (NCMAB) 2018, ISSN: 2621 1572, hal : $158-175$ 
Mareta, A. D. (2013). Pengaruh Financial Leverage Terhadap Profitabilitas (Studi Pada Perusahaan Sektor Makanan Dan Minuman Yang Terdaftar Di Bursa Efek Indonesia Periode 2009-2011). Jurnal Administrasi Bisnis, 1(2), 132-139

Nugroho, E. (2011). Analisis Pengaruh Likuiditas, Pertumbuhan Penjualan, Perputaran Modal Kerja, Ukuran Perusahaan dan Leverage terhadap Profitabilitas Perusahaan (Studi pada Perusahaan Manufaktur yang Terdaftar pada BEI pada Tahun 2005-2009). http://www.eprints.undip.ac.id.

Pongrangga, R A et al. (2015). Pengaruh Current Ratio, Total Asset Turm Over dan Debt to Equity Ratio Terhadap Return On Equity(Studi pada Perusahaan Sub Sektor Property dan Real Estate yang Terdaftar di BEI periode 20112014). Jurnal,. Universitas Brawijaya. Malang.

Prastowo, D. (2010). Analisis Laporan Keuangan Konsep Dan Aplikasi. Edisi Ke-3. Yogyakarta: UPP STIM YKPN.

Prastowo, D. (2015). Analisis Laporan Keuangan Konsep dan Aplikasi.Unit Penerbit dan Percetakan Sekolah Tinggi Ilmu Manajemen YKPN.Yogyakarta.

Prihadi, T. (2012).Memahami Laporan Keuangan Sesuai IFRS dan PSAK.Jakarta: PPM. 
Jufrizen \& Maya Sari : Pengaruh Current Ratio, Debt to Equity Ratio, dan Firm Size Terhadap ...

Riyanto, B. (2010). Dasar-dasar pembelanjaan perusahaan. BPFE: Yogyakart

Rosyadah, F, (2012). Pengaruh Struktur Modal Terhadap Profitabilitas (Studi Pada Perusahaan Real Estate and Property Yang Terdaftar di Bursa Efek Indonesia (BEI) Periode 2009 - 2011), Jurnal, Fakultas Ilmu Administrasi, Universitas Brawijaya Malang, Malang

Sartono, A. (2009). Manajemen Keuangan Teori dan Aplikasi. Edisi Keempat. Yogyakarta: BPFE.

Sawir, A. (2009). Analisa Kinerja Keuangan dan Perencanaan keauangan Perusahaan, Jakarta : PT. Gramedia Pustaka Utama.

Sefiani, C. Y. K. (2016). Pengaruh Current Ratio, Total Asset Turn Over, Dan Umur Perusahaan Terhadap Profitabilitas. Jurnal Ilmu \& Riset Manajemen, 4(11)

Singapurwoko, A. (2011). The Impact of Financial Leverage to Profitability Study of Non-Financial Companies Listed in Indonesia Stock Exchange. European Journal of Economics, Finance and Administrative Sciences. ISSN 1450-2275 Issue 32

Sujarweni, V.Wiratna. 2015. Metode Penelitian Bisnis dan Ekonomi, Yogyakarta: Pustaka Baru Press. 
Sujarweni, V. W. (2017). Analisis Laporan Keuangan. Pustaka Baru Press: Yogyakarta.

Utama, S. (2000).Teori dan Riset Akuntansi Positif : Suatu Tinjauan Literatur. Jurnal Ekonomi dan Bisnis Indonesia. No. 1 : 83-96

Wahyuni, S. F. (2017). Peran kepemilikan institusional dalam memoderasi pengaruh Current Ratio, Debt to Equity ratio, Total asset turnover dan inventory turnover terhadap Return On Equity di Bursa Efek Indonesia. Jurnal Riset Finansial Bisnis, 1(2), 147-158. 